\section{Analysis of the Early Stages and Evolution of Dental Enamel Erosion}

Juliana dos Reis Derceli ${ }^{1}$, Juliana Jendiroba Faraoni ${ }^{1}$, Marcelo Assumpção

Pereira-da-Silva ${ }^{2,3}$, Regina Guenka Palma-Dibb

The aim of this study was to evaluate by atomic force microscopy (AFM) the early phases and evolution of dental enamel erosion caused by hydrochloric acid exposure, simulating gastroesophageal reflux episodes. Polished bovine enamel slabs ( $4 \times 4 \times 2 \mathrm{~mm})$ were selected and exposed to $0.1 \mathrm{~mL}$ of $0.01 \mathrm{M}$ hydrochloric acid $(\mathrm{pH}=2)$ at $37{ }^{\circ} \mathrm{C}$ using five different exposure intervals ( $n=1)$ : no acid exposure (control), $10 \mathrm{~s}, 20 \mathrm{~s}, 30 \mathrm{~s}$ and 40 $s$. The exposed area was analyzed by AFM in 3 regions to measure the roughness, surface area and morphological surface. The data were analyzed qualitatively. Roughness started as low as that of the control sample, $R_{\text {rms }}=3.5 \mathrm{~nm}$, and gradually increased at a rate of 0.3 $\mathrm{nm} / \mathrm{s}$, until reaching $R_{\mathrm{rms}}=12.5 \mathrm{~nm}$ at $30 \mathrm{~s}$. After $40 \mathrm{~s}$, the roughness presented increment of $0.40 \mathrm{~nm}$ only. Surface area (SA) increased until $20 \mathrm{~s}$, and for longer exposures, the surface area was constant (at $30 \mathrm{~s}, \mathrm{SA}=4.40 \mu \mathrm{m}^{2}$ and at $40 \mathrm{~s}, \mathrm{SA}=4.43 \mu \mathrm{m}^{2}$ ). As regards surface morphology, the control sample presented smaller hydroxyapatite crystals $(22 \mathrm{~nm})$ and after $40 \mathrm{~s}$ the crystal size was approximately $60 \mathrm{~nm}$. Short periods of exposure were sufficient to produce enamel demineralization in different patterns and the morphological structure was less affected by exposure to hydrochloric acid over $30 \mathrm{~s}$.

\author{
'Department of Restorative Dentistry, \\ School of Dentistry of Ribeirão \\ Preto, USP - Universidade de São \\ Paulo, Ribeirão Preto, SP, Brazil \\ ${ }^{2}$ São Carlos Physics Institute, \\ USP - Universidade de São \\ Paulo, São Carlos, SP, Brazil \\ ${ }^{3}$ UNICEP - Paulista Central University \\ Center, São Carlos, SP, Brazil
}

Correspondence: Profa. Dra. Regina Guenka Palma Dibb, Avenida do Café, S/N, Monte Alegre, 14.040900 Ribeirão Preto, SP, Brasil. Tel: +55-163315-4016. e-mail: rgpalma@usp.br

Key Words: tooth erosion, tooth wear, atomic force microscopy, dental enamel, hydrochloric acid, gastroesophageal reflux.

\section{Introduction}

Dental erosion affects many adults and infants (13). Its etiology is associated with population changes, especially those that result in a diet that includes substantial consumption of acidic foods and drinks (3-4). In addition, a large number of individuals have diseases like anorexia nervosa, bulimia and gastroesophageal reflux disease (GERD), which facilitate the contact of gastric juice with the oral cavity (5-7).

GERD involves passage of gastric contents into the esophagus that eventually reaches the oral cavity. The acidic stomach contents refluxed into the oral cavity can dissolve tooth structures and cause erosive tooth wear (6-7), and contact between the hydrochloric acid from the stomach and the oral cavity occurs for a few seconds, several times a day.

The erosive lesions are characterized by irreversible, localized and chronic loss of mineral tissue that is chemically removed from the tooth surface by acidic, alkaline and chelating substances without the involvement of bacteria (5). Clinically eroded teeth exhibit enamel areas with brightness loss, flat surface area, and wide and shallow lesions without sharp angles. In restored teeth, the restorations become prominent, protruding above the tooth surface. When erosion affects the dentin, dentin hypersensitivity may occur (8).

Chemically, the erosive process involves hydrogen ions $\left(\mathrm{H}^{+}\right)$derived from weak and strong acids; these ions bind to carbonate and phosphate ions and remove these species from hydroxyapatite crystals (9). Water, carbonate and phosphate from the enamel are responsible for allowing acid diffusion into the dental substrate (9). In this way, the acidic substances start a demineralization process that leads to dental substrate softening and loss, especially if the acid exposure is long lasting and/or frequently repeated (10-14), as occurs in GERD.

The methodology used in these studies $(11,15-17)$ to perform the erosive process employs several acid solutions and different exposure times (60 - $750 \mathrm{~s}$ ). However, it is still unknown the action acid in short periods of time and how it affects the erosive process development and the methodology employed in the assessments of preventive materials. Thus, the aim of this study was to evaluate the beginning and process of the evolution of dental enamel demineralization caused by hydrochloric acid exposure, which simulates gastroesophageal reflux episodes.

\section{Material and Methods}

\section{Experimental Design}

This in vitro study evaluated bovine dental enamel exposure to hydrochloric acid for different durations, in order to understand the early stages of the erosion process. This study had only 1 study factor, the exposure to hydrochloric acid at 5 levels: no exposure and exposure to hydrochloric acid for $10 \mathrm{~s}, 20 \mathrm{~s}, 30 \mathrm{~s}$ and $40 \mathrm{~s}$. The experimental units were 5 fragments of bovine dental enamel, each of which was exposed at random to one of the 5 treatments. The variables were roughness, area, projected superficial area and surface morphology. All the 
parameters were assessed using atomic force microscopy.

\section{Sample Preparation}

Bovine teeth were cut at the cement enamel junction. The crowns were bisected longitudinally, and the buccal and lingual fragments were separated using a water-cooled diamond saw in a sectioning machine (Minitom, Struers $\mathrm{A} / \mathrm{S}$, Copenhagen, Denmark). The lingual fragment was discarded, and 5 enamel blocks of buccal specimens ( $4 \times 4$ $\mathrm{mm})$ were obtained. The specimens were flattened and polished with wet sandpaper (\#600 and \#1200-grit), felt discs and alumina suspensions ( 0.3 and $0.05 \mu \mathrm{m})$. After polishing, the specimens were divided into 5 groups $(n=1)$ according to hydrochloric acid exposition time: no exposure (control), $10 \mathrm{~s}, 20 \mathrm{~s}, 30 \mathrm{~s}$ and $40 \mathrm{~s}$.

\section{Erosive Challenge}

After cleaning the enamel fragment surfaces, each specimen was exposed to $0.1 \mathrm{~mL}$ of hydrochloric acid ( 0.01 $\mathrm{M}, \mathrm{pH}$ 2) at $37^{\circ} \mathrm{C}(18)$. The acid was applied to the enamel surface for predetermined periods of 10,20,30 and $40 \mathrm{~s}$ and then removed by deionized water. Then, the fragments were stored in deionized water for atomic force microscopy.

\section{A}

\section{Atomic Force Microscopy (AFM)}

The analyses were performed using an atomic force microscope (MultiMode 3; Digital Instruments Bruker, Santa Barbara, CA, USA; proprietary software: Nanoscope III 5.12b43) with a rectangular silicon cantilever, a spring constant of approximately $70 \mathrm{~N} / \mathrm{m}$, an oscillation frequency of $320 \mathrm{KHz}$. It was operated in intermittent contact mode (tapping mode), with a scanning frequency of $0.7 \mathrm{~Hz}$ per line and a $2 \mu \mathrm{m}$ scale. AFM allows for the analysis of roughness, surface morphology and surface area in 3 different points of specimens. For this study, the data were analyzed qualitatively.

\section{Results}

Table 1 lists the surface roughness values $\left(R_{r m s}\right.$ and $\left.R_{a}\right)$ of the analyzed samples. Roughness starts as low as that of control sample, $R_{r m s}=3.5 \mathrm{~nm}$, and increases gradually at a rate of $0.3 \mathrm{~nm} / \mathrm{s}$, until reaching $R_{r m s}=12.5 \mathrm{~nm}$ at 30 s. After $30 \mathrm{~s}$, the roughness rate decreased to $0.04 \mathrm{~nm} / \mathrm{s}$, reaching $R_{r m s}=12.9 \mathrm{~nm}$ at $40 \mathrm{~s}$. The same behavior was observed for $\mathrm{R}_{\mathrm{a}}$ (Table 1).

As regards the surface area of the fragments, a remarkable increase in the surface area was observed up to $20 \mathrm{~s}$ of exposure (SA=4.403 $\mu \mathrm{m}^{2}$, rate of 0.01395 $\mu \mathrm{m}^{2} / \mathrm{s}$ ). From $20 \mathrm{~s}$ to $40 \mathrm{~s}$, surface area fluctuated around $\mathrm{SA}=4.40 \mu \mathrm{m}^{2}$.

In Figure 1, which presents the observed data for roughness and surface area, there is a rapid increase in surface roughness during the first $30 \mathrm{~s}$ of exposure to hydrochloric acid and a tendency toward stability after $30 \mathrm{~s}$.

Figure 2 presents the nanostructure surface according to the length of exposure to hydrochloric acid. The presence of apatite crystals with an approximate diameter of 22 $\mathrm{nm}$ was observed in the control sample; in the sample exposed to acid for $40 \mathrm{~s}$, apatite crystals with diameters of approximately $60 \mathrm{~nm}$ were observed.

\section{Discussion}

Enamel is the exterior coating of the tooth, and its primary mineral component is hydroxyapatite $\left[\mathrm{Ca}_{10}\left(\mathrm{PO}_{4}\right)_{6}(\mathrm{OH})_{2}, \mathrm{HAP}\right]$. As the most highly mineralized (>95 wt \%) tissue in vertebrates, enamel is composed of numerous rod-like apatite crystals, which are bundled into ordered prisms (19). This compound is not stable and undergoes changes because of chemical interactions, such as calcium ion substitution by sodium, magnesium and potassium ions; the sodium ion is the most frequent participant in this substitution. The major change occurs when phosphate $\left(\mathrm{PO}_{4}\right)$ is replaced by carbonate $\left(\mathrm{CO}_{3}\right)$ because this replacement increases enamel's solubility. Some hydroxyl ions ( $\mathrm{OH}-)$ of hydroxyapatite are replaced by fluoride ions (F-), which generates fluorapatite, a more acid-resistant compound $(9,20)$.

Erosion may occur by continuous layer-by-layer dissolution of the enamel crystals, leading to a permanent loss of tooth volume and a softened layer at the surface of the remaining tissue (21). To obtain insight into the early stages of enamel dissolution, it is important to quantify this erosion, and it is essential to obtain precise measurements of the material loss as a function of time.

In the present in vitrostudy, AFM was used to investigate the surface alteration that occurs during the dental erosion process, which is produced by hydrochloric acid exposure. AFM was used to monitor and quantify the enamel surface mineral loss with high precision. AFM has previously been used to collect high-resolution images and to analyze the

Table 1. Roughness values $\left(\mathrm{R}_{\mathrm{rms}}\right.$ and $\left.\mathrm{R}_{\mathrm{a}}\right)$, surface area (SA) projected area (PA) and ratio (SA/PA) of enamel fragments exposed to hydrochloric acid

\begin{tabular}{lccccc}
\hline Sample & $\begin{array}{c}\mathrm{R}_{\mathrm{rms}} \\
(\mathrm{nm})\end{array}$ & $\begin{array}{c}\mathrm{R}_{\mathrm{a}} \\
(\mathrm{nm})\end{array}$ & $\begin{array}{c}\text { Surface } \\
\text { area (SA) } \\
\left(\mu \mathrm{m}^{2}\right)\end{array}$ & $\begin{array}{c}\text { Projected } \\
\text { area (PA) } \\
\left(\mu \mathrm{m}^{2}\right)\end{array}$ & $\begin{array}{c}\text { Ratio } \\
\text { SA/PA (\%) }\end{array}$ \\
\hline Control & 3.5 & 2.6 & 4.124 & 4.000 & 3.1 \\
$10 \mathrm{~s}$ & 6.9 & 5.3 & 4.284 & 4.000 & 7.1 \\
$20 \mathrm{~s}$ & 9.7 & 7.4 & 4.403 & 4.000 & 10.1 \\
$30 \mathrm{~s}$ & 12.5 & 9.6 & 4.389 & 4.000 & 9.7 \\
$40 \mathrm{~s}$ & 12.9 & 10.4 & 4.430 & 4.000 & 10.8 \\
\hline
\end{tabular}


enamel surface. Thus, AFM has become an important source of new structural information (22).

The intensity of dental surface erosion depends on the immersion time, frequency and acid type (10-12). These acids may be of extrinsic or intrinsic origin; the intrinsic acids typically consist of hydrochloric acid from the stomach which contacts the oral cavity by GERD-induced reflux. This disease is a common condition, with a high prevalence, ranging from 10 to 20 percent of the population in Western countries $(23)$. Literature $(5,24)$ indicates that the prevalence of dental erosion in patients with GERD is approximately $47.5 \%$ (5).

Therefore, in the present study, gastroesophageal reflux episodes were simulated using hydrochloric acid (0.01 M, $\left.\mathrm{pH} 2.0,37^{\circ} \mathrm{C}\right)(18)$. In the experiments, enamel fragments were exposed to hydrochloric acid for short periods of time and demineralization was observed to increase gradually as the exposure time increased; this finding is similar to the results reported in the literature (11-14). However, for the exposure period between 30 and $40 \mathrm{~s}$, the hydrochloric acid erosion rate decreased by approximately 7.5 times compared with the rate observed during the initial periods. In the analysis of enamel fragments, a sharp increase in surface area was observed in the first 20 s of acid exposure; after this period, the rate of surface area increase decreased by approximately 10.3 times.
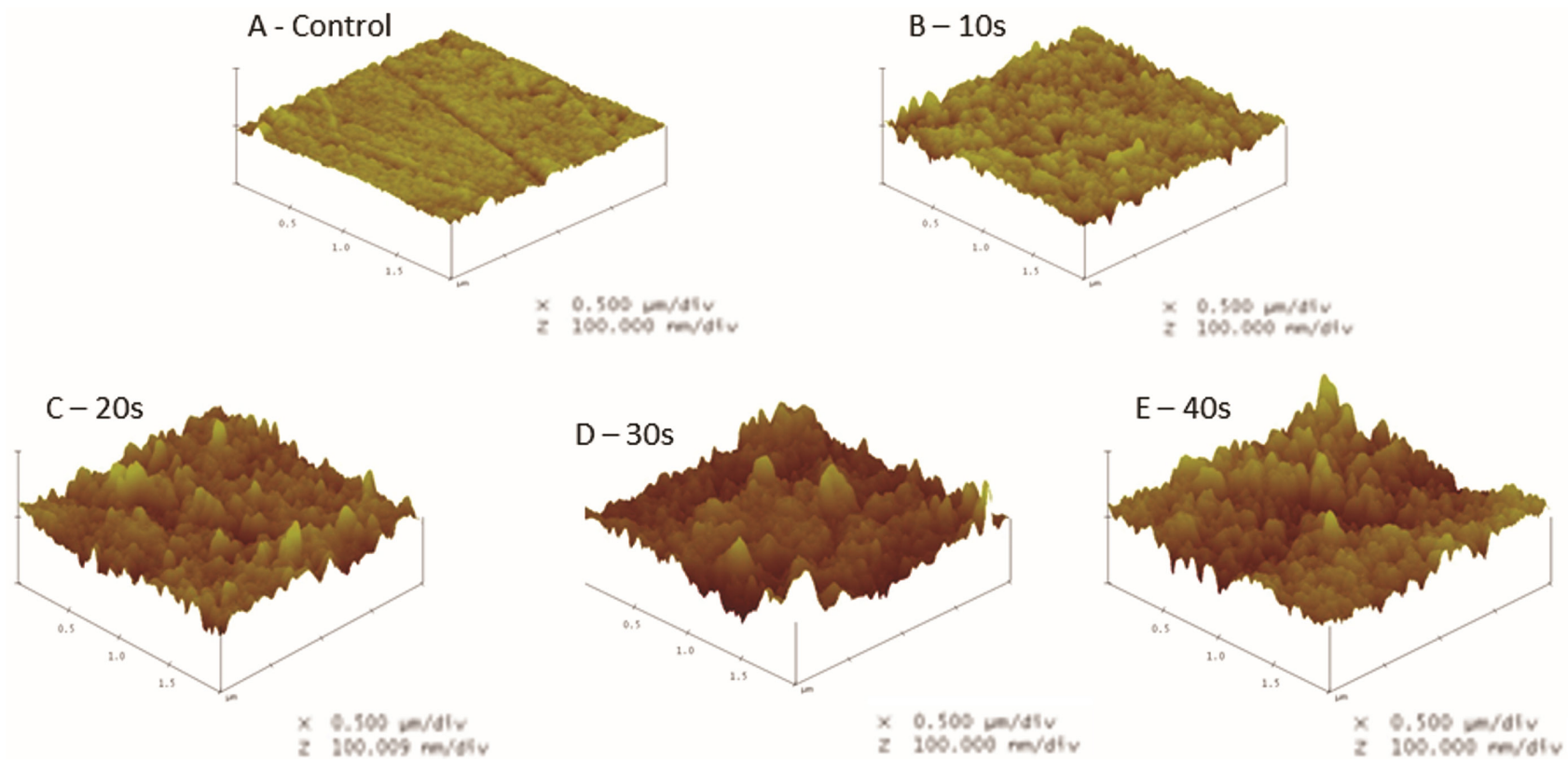

Figure 1. 3D images of the enamel fragment surface (A-E) according to the length of hydrochloric acid exposure, illustrating the increased surface roughness of the fragments.

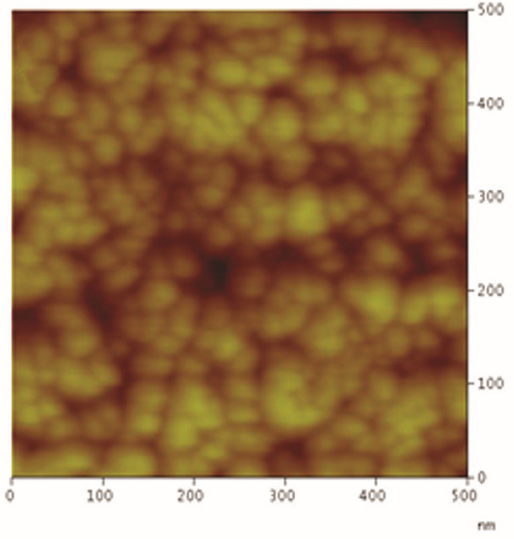

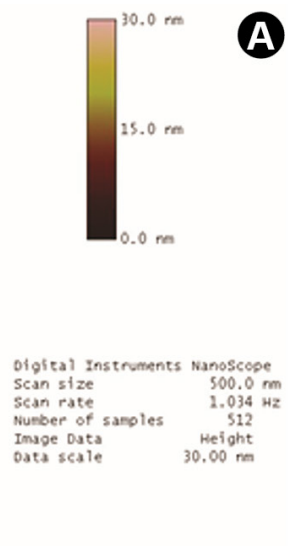
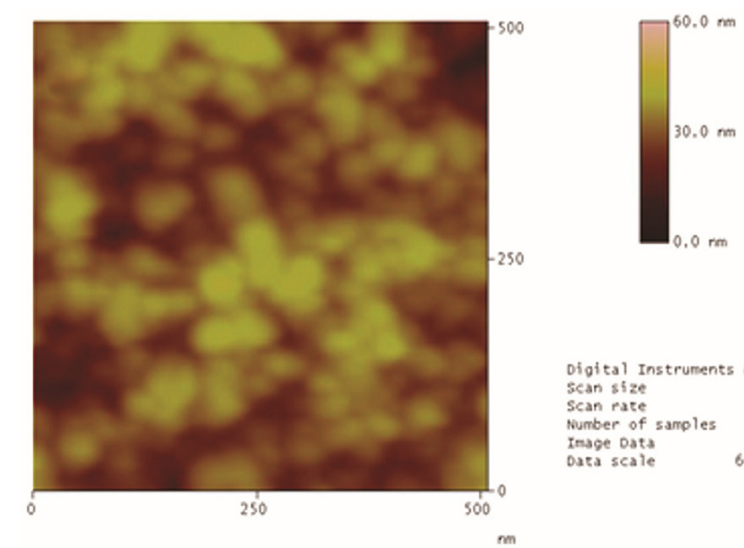

B

$5405 z .008$ 
This trend is possibly due to the large number of hydroxyapatite crystals with small diameters, which provided a greater surface area and more rapid demineralization. As the smaller crystals were removed, the relatively large diameters of the remaining crystals and the larger spaces between them caused the demineralization and surface area rate to decrease. The exposed larger crystals have also been suggested to be more acid-resistant, which would affect the development process, as the enamel presents areas that are more easily demineralized $(25,26)$. Apatite crystal structure heterogeneity (27) may also play a role in this trend, as well as the different crystal arrangements in the enamel (28-30).

This suggests that the demineralization pattern is cyclic: the initial demineralization rate is high and then decreases as demineralization progresses; however, after the elimination of larger hydroxyapatite crystals and the exposure of smaller crystals, the demineralization rate increases again. To understand this process are required studies that allow for insight into the continuity of the entire demineralization process and to monitor the entire process. However, in vitro studies present some limitation for not representing $100 \%$ of the oral conditions. In relation $\vec{s}$ to the equipment, the acquisition of high resolution images was a very slow process. Moreover, the data apply only to the situation mediated by hydrochloric acid, as occurs in GERD.

Several studies have demonstrated that the early stages of erosion result in the softening of the enamel surface up to a certain depth $(11,15-17)$; however, these studies of enamel exposure to acid solutions were performed for periods longer than $1 \mathrm{~min}$. According to this study, it would not be effective because exposure times longer than $20 \mathrm{~s}$ do not demonstrate a real increase in the progression of the erosive process.

In the present study, the enamel fragments were exposed to hydrochloric acid for short periods of time, ranging from 10 to $40 \mathrm{~s}$. These exposures were sufficient to observe changes and superficial substrate loss, as such short periods of exposure to hydrochloric acid, which occur in situations like GERD, are sufficient to cause enamel demineralization and substantial loss of structure over time.

\section{Resumo}

0 objetivo deste estudo foi avaliar os estágios iniciais e a evolução da erosão do esmalte dental causado pela exposição ao ácido clorídrico, simulando assim episódios de refluxo gastroesofágico, usando um microscópio de força atômica (AFM). Fragmentos de esmalte bovino planificados e polidos $(4 \times 4 \times 2 \mathrm{~mm})$ foram selecionados e exposto a $0,1 \mathrm{~mL}$ de ácido clorídrico $0,01 \mathrm{M}(\mathrm{pH}=2)$ a $37{ }^{\circ} \mathrm{C}$, utilizando cinco intervalos diferentes de exposição: sem exposição ao ácido (controle) e $10 \mathrm{~s}, 20 \mathrm{~s}$, 30 s e 40 s. Então, a área exposta foi analisada com AFM em 3 regiões diferentes para mensurar a rugosidade, a área da superfície e a morfologia superficial. Os dados foram analisados qualitativamente. Inicialmente, a rugosidade apresentou valor baixo como a amostra controle, $R_{r m s}=3,5$ $\mathrm{nm}$, e aumentou gradualmente a uma taxa de $0,3 \mathrm{~nm} / \mathrm{s}$, até $R_{\mathrm{rms}}=12,5$ $\mathrm{nm}$ a $30 \mathrm{~s}$. Após $40 \mathrm{~s}$, a rugosidade apresentou um incremento de apenas $0,40 \mathrm{~nm}$. Área de superficie (SA) aumentou até $20 \mathrm{~s}$, e para exposições mais longas, a área de superficie manteve-se constante ( $30 \mathrm{~s}, 0 \mathrm{SA}=4,40$ $\mu \mathrm{m}^{2}$, e em $40 \mathrm{~s}$, a $S A=4,43 \mu \mathrm{m}^{2}$ ). Em relação à morfologia superficial, a amostra controle apresentou cristais de hidroxiapatita menores $(22 \mathrm{~nm})$, e após 40s o tamanho do cristal era de aproximadamente $60 \mathrm{~nm}$. Períodos curtos de exposição foram suficientes para produzir a desmineralização do esmalte em diferentes padrões e a estrutura morfológica foi menos afetada pela exposição ao ácido clorídrico acima de $30 \mathrm{~s}$.

\section{Acknowledgements}

This study was supported by FAPESP (Fundação de Amparo à Pesquisa do Estado de São Paulo \#2010/19531-8 and \#2011/12901-7).

\section{References}

1. Kirthiga $M$, Poornima $P$, Praveen $R$, Sakeena $B$, Disha P. Dental erosion and its associated factors in 11-16-year old school children. J Clin Pediatr Dent 2015;39:336-342.

2. Jaeggi T, Lussi A. Prevalence, incidence and distribution of erosion. Monogr Oral Sci 2014;25:55-73.

3. Salas MM, Nascimento GG, Vargas-Ferreira F, Tarquinio SB, Huysmans $M C$, Demarco FF. Diet influenced tooth erosion prevalence in children and adolescents: Results of a meta-analysis and meta-regression. J Dent. 2015;43:865-875.

4. Bertoldi C, Lucchi A, Zaffe D. Effects of soft-drinks and remineralising treatment on teeth assessed by morphological and quantitative X-ray investigations. Eur J Paediatr Dent. 2015;16:263-271.

5. Benages A, Muñoz JV, Sanchiz V, Mora F, Mínguez M. Dental erosion as extraoesophageal manifestation of gastro-oesophageal reflux. Gut 2006;55:1050-1051.

6. Moazzez R, Bartlett D. Intrinsic causes of erosion. Monogr Oral Sci 2014;25:180-196.

7. Bartlett DW, Evans DF, Anggiansah A, Smith BG. A study of the association between gastro-oesophageal reflux and palatal dental erosion. Braz Dent J 1996;181:125-131.

8. West N, Seong J, Davies M. Dentine hypersensitivity. Monogr Oral Sci 2014;25:108-122.

9. Featherstone JD, Lussi A. Understanding the chemistry of dental erosion. Monogr Oral Sci 2006;20:66-76.

10. Johansson AK, Lingström $P$, Imfeld $T$, Birkhed D. Influence of drinking method on tooth-surface $\mathrm{pH}$ in relation to dental erosion. Eur J Oral Sci 2004;112:484-489.

11. Cheng ZJ, Wang XM, Cui FZ, Ge J, Yan J X. The enamel softening and loss during early erosion studied by AFM, SEM and nanoindentation. Biomed Mater 2009;4:1-7.

12. Voronets J, Lussi A. Thickness of softened human enamel removed by toothbrush abrasion: an in vitro study. Clin Oral Investig 2010;14:251256.

13. Fujii M, Kitasako Y, Sadr A, Tagami J. Roughness and pH changes of enamel surface induced by soft drinks in vitro applications of stylus profilometry, focus variation 3D scanning microscopy and micro $\mathrm{pH}$ sensor. Dent Mat J 2011;30:404-410.

14. Scaramucci T, Sobral MAP, Eckert GJ, Zero DT, Hara AT. In situ evaluation of the erosive potential of orange juice modified by food additives. Caries Res 2012;46:55-61.

15. Lussi A, Kohler N, Zero D, Schaffner M, Megert B. A comparison of the erosive potential of different beverages in primary and permanent teeth using an in vitro model. Eur J Oral Sci 2000;108:110-114.

16. Lippert F, Parker DM, Jandt KD. Susceptibility of deciduous and permanent enamel to dietary acid-induced erosion studied with atomic force microscopy nanoindentation. Eur J Oral Sci 2004;112:61-66.

17. Watari F. In situ quantitative analysis of etching process of human teeth by atomic force microscopy. J Elect Microsc 2005;54:299-308.

18. Austin RS, Stenhagen KS, Hove LH, Dunne S, Moazzez R, Bartlett DW, et al.. A qualitative and quantitative investigation into the effect of 
fluoride formulations on enamel erosion and erosion-abrasion in vitro. J Dent 2011;39:648-655.

19. Berkovitz BKB, Holland GR, Moxham BJ. A colour atlas and text of oral anatomy, histology and embryology. Wolfe Publishing, Aylesbury, 1992.

20. LeGeros RZ. Calcium phosphates in oral biology and medicine. Monogr Oral Sci 1991;15:108-129.

21. Lussi A, Schlueter N, Rakhmatullina E, Ganss C. Dental erosion - an overview with emphasis on chemical and histopathological aspects. Caries Res 2011;45:2-12.

22. Farina M, Schemmel A, Weissmuller G, Cruz R, Kachar B, Bisch PM. Atomic force microscopy study of tooth surfaces. J Struct Biol 1999;125:39-49.

23. Dent J, El-Serag HB, Wallander MA, Johansson S. Epidemiology of gastro-oesophageal reflux disease: a systematic review. Gut 2005;54:710-717.

24. Tantbirojn D, Pintado MR, Versluis A, Dunn C, Delong R. Quantitative analysis of tooth surface loss associated with gastroesophageal reflux disease. A longitudinal clinical study. J Am Dent Assoc 2012;143:278285.

25. Robinson C, Simon C, Kirkham J, Brookes SJ, Shore R, Smith A.
Dental enamel-a biological ceramic: regular substructures in enamel hydroxyapatite crystals revealed by atomic force microscopy. J Mater Chem 2004;14:2242-2248.

26. Pan H, Tao J, Yu X, Fu L, Zhang J, Zeng X, et al.. Anisotropic demineralization and oriented assembly of hydroxyapatite crystals in enamel: Smart Structures of Biominerals. J Phys Chem 2008;112:71627165.

27. Fincham AG, Moradian-Oldak J, Simmer JPJ The structural biology of the developing dental enamel matrix. J Struct Biol 1999;126:270-299.

28. Jeng YR, Linm TT, Shieh DB. Nanotribological characterization of tooth enamel rod affected by surface treatment. J Biomech 2009;42:22492254.

29. Raue $\mathrm{L}$, Klein H. Location depending textures of human dental enamel. Solid State Phenomena 2010;160:281-286

30. Lu C, Nakamura T, Korach CS. Effective property of tooth enamel: Monoclinic behavior. J Biomech 2012;45:1437-1443.

Received November 27, 2015 Accepted April 6, 2016 